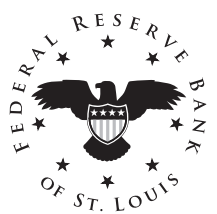

\title{
Strategic Social Responsibility
}

\author{
Rubén Hernández-Murillo
}

$\mathrm{C}$ orporate social responsibility (CSR) is a concept that promotes expanded social stewardship by businesses and organizations and has gained popularity in recent years. CSR suggests that corporations embrace responsibilities toward a broader group of stakeholders (customers, employees, and the community at large) in addition to their customary financial obligations to shareholders. Social activists often pressure corporations to engage in CSR by integrating some ethical feature in their product or undertaking some type of social investment. Firms are also ranked in terms of their CSR.

Although some economists are concerned about the viability of CSR in a competitive environment, recent studies suggest that engaging in CSR can be consistent with profit-maximization behavior. These studies argue that CSR can be considered a form of strategic investment for building and maintaining the firm's reputation. Other benefits derived from CSR may include the ability to charge a premium for products or the ability to recruit and retain certain types of workers. In fact, consumers' shopping patterns suggest that some socially concerned individuals are willing to pay a price premium for goods that incorporate a social or ethical component (e.g., hybrid automobiles or beauty products not tested on animals) because they value these characteristics.

Economists Donald Siegel and Donald Vitaliano analyzed the role of CSR as a signaling device to convey information about the firm's product quality. ${ }^{1}$ Their study of a large sample of publicly traded firms classified the firms using North American Industry Classification System codes into the following five categories: search goods (those whose quality can be readily evaluated before purchase, e.g., clothing, footwear, furniture); nondurable experience goods (those whose quality is experienced over multiple uses and frequent purchases, e.g., food, health and beauty products); durable experience goods (those that must be consumed before their true value can be determined, permit less learning from repeated purchases, and require a longer period for the product's characteristics to be fully known, e.g., automobiles, appliances); and finally, experience services and credence services (those that often involve strong information asymmetries between sellers and buyers, who may find it difficult to assess the service's value even over a long period, e.g., banking, financial counseling, auto repairs, weight loss programs).
Siegel and Vitaliano found that firms selling experience and credence goods and services are more likely to engage in CSR than those selling search goods. The difference is explained by consumers' perception of a firm's involvement in CSR (even when its product does not directly include an ethical component) as a valuable signal, particularly when associated with upscale goods and services for which prices do not convey all the necessary information about the firm's reliability and its commitment to quality and honesty. Among the firms listed in the "100 Best Corporate Citizens" ranking for 2007, only one-fourth produce search and nondurable experience goods; the remaining 75 percent produce durable experience goods or experience or credence services (see chart). ${ }^{2}$ These findings suggest that engaging in CSR activities can be a rational and crucial profit-maximization decision regarding a firm's differentiation strategy.
${ }^{1}$ Siegel, Donald S. and Vitaliano, Donald F. "An Empirical Analysis of the Strategic Use of Corporate Social Responsibility." Journal of Economics and Management Strategy, Fall 2007, 16(3), pp. 773-92.
2 This ranking by the Corporate Responsibility Office evaluates the social perform- ance of approximately 1,000 publicly held U.S. corporations (roughly the same universe of firms analyzed by Siegel and Vitaliano) on several categories, including financial performance, accountability toward local communities, governance, fairness to employees, environmental responsibility, human rights, and product characteristics; the complete list for the "100 Best Corporate Citizens" is at www.thecro.com/files/100BestGatefold.pdf.

\section{Best Corporate Citizens, 2007}

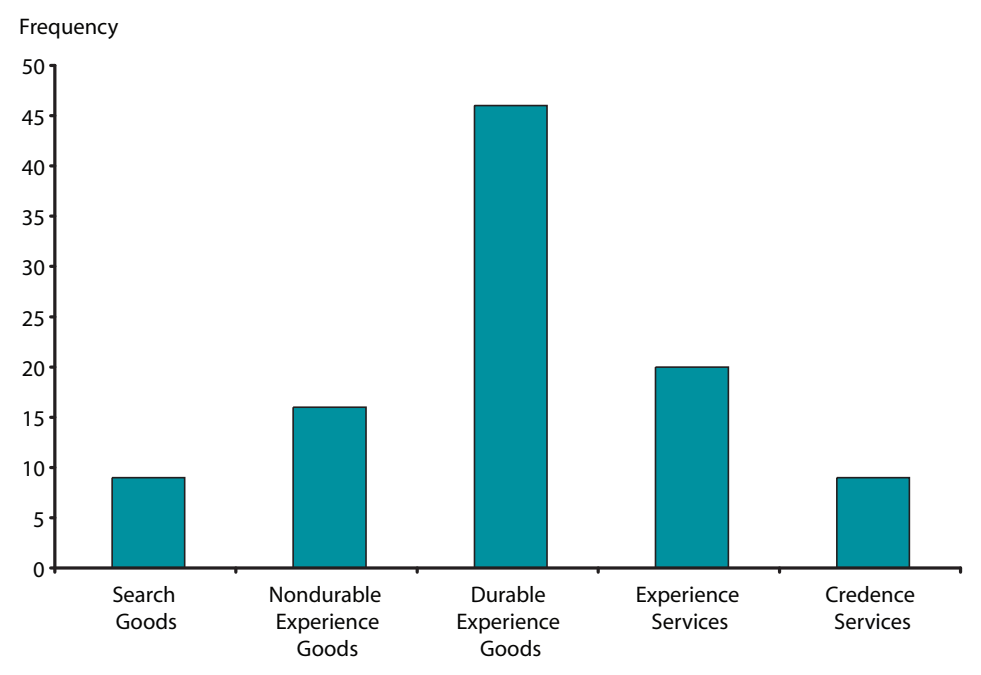

